\title{
Valuing subjectivity in journalism: Bias, emotions, and self-interest as tools in arts reporting
}

\author{
Phillipa Chong \\ McMaster University, Canada
}

\begin{abstract}
This article examines the meanings and norms surrounding subjectivity across traditional and new forms of cultural journalism. While the ideal of objectivity is key to American journalism and its development as a profession, recent scholarship and new media developments have challenged the dominance of objectivity as a professional norm. This article begins with the understanding that subjectivity is an intractable part of knowing (and reporting on) the world around us to build our understanding of different modes of subjectivity and how these animate journalistic practices. Taking arts reporting, specifically reviewing, as a case study, the analysis draws on interviews with 40 book reviewers who write for major American newspapers, including The New York Times, The Los Angeles Times, The Washington Post, and prominent blogs. Findings reveal how emotions, bias, and self-interest are salient - sometimes as vice and sometimes as virtue - across the workflow of critics writing for traditional print outlets and book blogs and that these differences can be conceptualized as different epistemic styles.
\end{abstract}

\section{Keywords}

Blogs, emotion, literary journalism, newspapers, online media, practice, subjectivity/ objectivity

\section{Introduction}

Objectivity has long been the gold standard in American journalism and was key to its development into a profession (Benson and Neveu, 2005; Schudson, 1976). Yet

Corresponding author:

Phillipa Chong, Department of Sociology, McMaster University, 609 Kenneth Taylor Hall, 1280 Main Street West, Hamilton, ON L8S 4M4, Canada.

Email: chong@mcmaster.ca 
scholars have complicated the picture by pointing to the unattainability of objectivity as an ideal with some noting the increasing acceptance of subjectivity across different forms of journalism (Tumber and Prentoulis, 2003; Wahl-Jorgensen, 2012, 2013; Zelizer, 2009b). Specifically, the current media landscape, with its new technological affordances (Ottovordemgentschenfelde, 2016; Rettberg, 2008) and organizational structures (Lowrey, 2006) including blogs and other forms of online reporting, is facilitating more personalized, participatory forms of journalism, which seem at odds with the traditional 'paradigm of objectivity' (Hackett, 2009; Reese, 1990).

In examining the relationship between traditional and new forms of journalism, scholars have come to mixed conclusions. On the one hand, some scholars have found evidence of blogs promoting alternative - and sometimes oppositional - journalistic values and practices compared to traditional journalism (Boczkowski, 2005; Perlmutter and Schoen, 2007; Turner, 2010). On the other hand, many studies have observed various degrees of overlap in practices across new and traditional forms of journalism, suggesting a more complementary relationship between the two (Blaagaard, 2013; Garden, 2016; Reese et al., 2007; Singer, 2005; Vos et al., 2012). Many studies take the analytical approach of treating traditional journalistic values as the norm from which new media practices deviate (Deuze et al., 2008; Mitchelstein and Boczkowski, 2009); for example, a study might consider to what extent bloggers and journalists working in other forms of new media stray from the traditional journalistic norms associated with objectivity (Agarwal and Barthel, 2015; De Zúñiga et al., 2011).

I offer a different analytical approach. Rather than making distinctions in terms of how traditional and new media journalists regard objectivity, for example, as a standard of traditional journalism, I begin with the understanding that subjectivity is an intractable part of how we know the world. And I examine the different ways subjectivity manifests and animates traditional and new media reporting of the same.

To do so, the article focuses on how subjectivity is understood by book reviewers as a specific form of cultural journalism. Book reviewers are an ideal case study because subjectivity is largely understood as inseparable from the task of reporting on arts and culture (Harries and Wahl-Jorgensen, 2007; Jaakkola, 2015). And in the realm of fiction reviewing, critics cannot deny subjectivity as illegitimate and must instead develop norms for incorporating it into their work (Chong, 2013). Furthermore, the realm of cultural journalism, like other journalistic fields, has been transformed and challenged by the growth of new media reporting in blogs and other online venues. This enables us to examine how subjectivity is understood, and perhaps handled differently, across forms of journalism. Hence, this article addresses two questions: (1) how do the norms of subjectivity operate? And (2) what can this teach us about the changing relation between blogging and traditional forms of journalism?

\section{The multiple modes of subjectivity}

The unattainability of objectivity as an ideal in journalism is well established. Even if fact-based reporting remains a popular benchmark of good journalism, media scholars have pointed out that news-making is intrinsically selective, partial, and thereby subjective in its practice (Gamson, 1989; Tuchman, 1972). Recent work has 
begun empirically investigating how subjectivity can co-exist with, if not complement, objective journalistic practices. What studies in this vein have shown is that more than being tolerated, infusing journalism with the emotional (as opposed to factual reporting) can enhance journalistic imperatives of engaging readers and communicating information.

A particularly striking example of the embrace of subjectivity comes from WahlJorgensen's (2012, 2013) studies of Pulitzer prize-winning journalism. Wahl-Jorgensen finds that these highly legitimated journalistic pieces frequently employ emotionality - often understood as a foil to rational fact-based journalism - to create more engaging reporting and to more effectively convey information. She concludes that not only does the inclusion of emotions not challenge the quality or claims to objectivity of the stories produced, but it can also be used to enhance the legitimacy of the journalist. She argues, 'subjectivity is now a deeply embedded tool of the journalistic profession' (WahlJorgensen, 2013: 317).

There are specific rules and parameters by which subjectivity is legitimately incorporated into journalism, however. Pantti (2010) examines the use of emotionality in television reporting and finds that, while there is openness to emotions as a way of facilitating communication of information, there are still right and wrong ways to incorporate emotions. For example, the skillful inclusion of emotions expressed by sources or informants could enhance the story being reported. But Pantti (2010) explains, 'the idea of journalists themselves being a locus of emotion was commonly rejected' (p. 176; emphasis added). Therefore, while subjectivity - including emotionality - may be an increasingly recognized and accepted part of journalistic practice, the subjectivity of the journalist as part of the journalistic process of writing is still perceived as being at odds with 'quality reporting'. I argue, however, that we can benefit from studying not just rules for wielding subjectivity as a rhetorical tool for building compelling news stories but as an intrinsic part of news-making as an epistemic practice.

I offer that it is useful to conceptualize the different ways that subjectivity is deployed as comprising distinct epistemic styles (cf. Maienschein, 1991). This refers to different approaches to solving problems related to knowledge-making. The present concern is epistemic insomuch as debates about subjectivity in journalism are fundamentally about the appropriate means by which we process and produce information about the world around us. And these norms coalesce into distinctive stylized representations of the self as active in the knowledge-making process across traditional print and new media arts journalism.

This approach builds upon studies in the sociology of knowledge pointing to subjectivity as part of the knowledge-making process in fields where objectivity is prized, including law (Clair and Winter, 2016; Jasanoff, 2011) and science (Daston and Galison, 2007; Langfeldt, 2004; Travis and Collins, 1991). However, many studies have been content with offering what Shapin (2012) describes as a 'dustbin' conception of subjectivity, which 'holds the heterogeneous bits and pieces of whatever it is that makes trouble for objectivity-stories' (p. 3). 1 That is, previous studies have stopped short of precisely articulating the specific modes of subjectivity and how they operate in knowledge-making. This article attempts to redress this by attending to norms for inclusion of 
subjectivity in reporting: What are some of its different forms? And what are the norms surrounding its deployment?

A review of studies of journalistic objectivity reveals at least three modes of subjectivity relevant for examination: bias, emotions, and self-interest.

Bias

This refers to prejudices or inferences based on individual assumptions rather than the 'reality' of a situation and is tied to norms of fairness and representation in journalism (Kovach and Rosenstiel, 2001). Social psychological studies suggest that we all carry prejudices or biases in the form of cultural schemas (Fiske, 1993; Ridgeway, 2013). A common example of prejudice or bias in reporting concerns political motivations (Hackett, 2009). Some argue for interpretive work in journalism in recognition of evidence that bias and prejudice are part of regular journalistic practice (Robinson and Culver, 2016; Ward, 2015). But in its most problematic formulation, bias can lead to distortions if journalists use their individual opinions, rather than facts, as a 'lens' through which to make sense of and report on issues.

\section{Emotions}

The dualism of emotionality and rationality, passion and reason, is widely known. Emotions are understood as private and highly personalized phenomena (Turner and Stets, 2006) and, as such, seen as out-of-place in public debate (Barnes, 2008; Calhoun, 2008). Emotionality is often treated as a marker of problematic journalism and associated with the sensationalism of tabloid journalism or opinion media (Jacobs and Townsley, 2011; Peters, 2011), whereas objective reporting is impersonal and 'cool, rather than emotional' in tone (Schudson, 2001: 150), in American journalism. However, Coward (2013) notes that first-person and related forms of journalism that feature emotions and private experiences are on the rise.

\section{Self-interest}

Another form of subjectivity is self-interest. The animating dynamic of this form of subjectivity is a perceived competition between commitments to the self, on one hand, and an external audience, on the other. In journalism, the assumption is that journalists have particular commitments or 'loyalties' to their readers in terms of providing fair and balanced information about the world around them (Kovach and Rosenstiel, 2001). Recent studies suggest that commercial pressures and incentives may be competing with traditional journalistic values in how journalists conceptualize their responsibilities to the reading public (Andersson and Wadbring, 2015; Christin, 2016; Hellman and Jaakkola, 2012). This is exacerbated by the increasing competitiveness of the journalistic field and the growth of new media, such as Twitter and blogs, and their incumbent emphasis on individual brands (Ottovordemgentschenfelde, 2016), suggesting that questions of how to balance self-interest and public interest are likely to become increasingly salient for new generations of journalists. 
Attending to how the above forms of subjectivity are managed alongside - rather than despite the norms of objectivity can help us understand both journalistic practices in general and the interrelations between new and traditional forms. I demonstrate the value of this approach through a case study of a particular type of reporting wherein subjectivity is embraced as a tool for journalistic practice.

\section{A case study of cultural journalism}

Cultural journalism encompasses the subset of normal journalism specializing in arts and entertainment. In addition to informing the general public about new cultural events and figures, this form of journalism includes reviews (Jaakkola, 2015). Book reviews serve the purpose of providing information to the public about what new books are being published and what new ideas are being circulated as part of the cultural conversation (Janssen, 1997).

Book reviews also contain opinions and literary judgments, which, as aesthetic matters, are often understood as inherently subjective or a 'matter of taste' (Chong, 2013; Shapin, 2012). The explicit interpretive and evaluative component to book reviewing makes it an excellent case for the examination of subjectivity. Research elsewhere demonstrates that arts journalists especially freelance critics who are the focus of this study 2 - see themselves as standing apart from mainstream journalists in their attitudes toward objectivity as a prerequisite for good journalistic practice (Harries and WahlJorgensen, 2007: 630). Book reviewing is thus an especially useful case for examining the rules and norms by which subjectivity is deployed in arts journalism because respondents are not entirely beholden to a professional ideology of objectivity to maintain their sense of professional legitimacy (cf. Schudson, 2001).

Additionally, the authority and practices of those who publish reviews in traditional outlets such as those found in newspapers like The New York Times are being challenged by new modes of disseminating information about new books, including new media outlets such as blogs (Verboord, 2009). These conditions make book reviewing a useful case for understanding not only the rules for varieties of subjectivity but also how these vary between online and traditional journalistic forms.

\section{Data and methods}

The research is based on in-depth interviews with a total of 40 book reviewers and is part of a larger project on exploring the shifting self-understandings of book reviewers at a time when 'everyone's a critic'. In order to select interviewees, I began by generating a list of names of everyone who had published at least one fiction review in one of three major national papers (which I do not identify in order to protect the anonymity of my respondents). These were selected through the following combination of criteria: (1) the publications had among the largest circulation numbers, (2) comparable readership demographics, and (3) a reputation for arts/culture reviewing. After deleting multiple entries, this process generated a list of over 1000 names of people from which I began random sampling. Although I used only three publications to generate my initial population of reviewers, all of my informants have reviewed for multiple publications, among them The New York Times, The Los Angeles Times, The Washington Post, The Chicago 
Tribune, The New Yorker, The Guardian (United Kingdom), The Times (United Kingdom), and other news outlets.

I supplemented this sample by reaching out to bloggers who were identified as particularly influential in the literary field. There are many challenges when it comes to sampling blogs ( $\mathrm{Li}$ and Walejko, 2008). I selected bloggers to interview in two ways: I consulted at several lists of 'Top 10 bloggers' published in various outlets, aggregating the named sites and randomly sampling from this list, and I asked respondents selected in the first stage of sampling (i.e. from newspaper media) about bloggers they followed or knew about (whether they liked them or not). The data here are by no means meant to be a representative sample of book bloggers; however, it does reflect a range of voices and bloggers who are recognized as impactful within the book-reviewing world.

The majority of reviewers are 'occasional' reviewers, meaning that in addition to writing reviews they make their living through freelance journalism, as novelists or teachers, or through a combination of the above. However, critics have been shown to take their role as journalists seriously even if it is an occasional activity (Chong, 2015). While some respondents might primarily write for online-only publications, after conducting interviews it became apparent that only one of them wrote exclusively for a personal blog. This overlap between so-called amateur reviewing on blogs and professional reviewing for print newspapers suggests that new media is allowing amateurs to enter the more closed world of literary professionals. It further implies some fluidity in identity, as elite bloggers often transition in and out of the role of the professional reviewer.

Interviews were conducted over the telephone, generally lasting between 60 and 90 minutes. During this time, critics were asked to reflect upon how they understood their role and goals as book reviewers, their review practices/routines, and the ethics of reviewing. The goal of this questioning was to provide a portrait of the customary rules (Lamont, 2009) of book reviewing, which refer to the taken-for-granted norms governing what is considered appropriate behavior for social actors engaged in evaluation. These rules range from substantive issues (i.e. what criteria are 'irrelevant') to epistemic issues (i.e. bracketing self-interest), and the fairness and legitimacy of a review are understood as the 'collective outcome' of following these rules (Lamont and Huutoniemi, 2011). When critics revealed that they wrote about books for both blogs and traditional media, I asked them to reflect on similarities and differences in their experience or understanding of reviewing in both situations.

These interviews were recorded and transcribed word-by-word. I first performed a thematic analysis (Boyatzis, 1998) involving a broad and inductive reading of the data to uncover themes regarding the customary rules of book reviewing at its different stages. I then conducted additional coding focused on customary rules concerning critics' management of different forms of subjectivity across traditional news outlets and personalized blogs. The results emerging from this additional analysis are reported below.

A final point about data and methods: one concern with interview data is the extent to which respondents may be engaging in highly principled and positive self-presentation when answering questions restricting their comments to the realm of the 'honorific' (Pugh, 2013). While I designed the interview questionnaire to encourage critics to ground their responses in specific and concrete review assignments and examples, the validity of 
this article does not depend on the extent to which critics' responses match perfectly with their practices. The empirical goal is documenting the acceptable norms guiding the use of subjectivity in reviewing, which can be gleaned by respondents stated adherence, failure, or aspiration to the same (irrespective of the 'reality' of their practices). The foregoing analysis, then, represents the customary rules regarding the deployment of subjectivity across traditional and new media forms of reviewing.

\section{Stylized approaches to bias, emotion, and self-interest in print and blogs}

Critics are aware that reviews are subjective. As one long-time West-coast critic explained, 'Reading is a really subjective process and so reviewing - well, reviewing is obviously ... subjective'. However, to say that critics' reviewing practices are subjective, in the sense of being entirely idiosyncratic, unreasoned, or irrational, is to misunderstand their meaning.

Below, I detail the multiple forms of subjectivity that critics encounter as an intrinsic part of their journalistic practice. Each mode of subjectivity represents a different way that critics recognize themselves as active, rather than 'neutral', agents in the knowing and reporting process. Additionally, I examine the diverging strategies that critics develop for managing bias, emotion, and self-interest when writing for traditional print publications and blogs - specifically, decisions about whether to feature or obscure in this process. How critics embrace and incorporate each mode of subjectivity can be understood as comprising distinct epistemic styles.

\section{Taste as aesthetic bias}

Concerns about bias are front and center in book reviewing. Bias takes the form of personal preferences, or taste, which manifested as recognition of the fact that certain people just do not like certain kinds of books. 'Aesthetic bias', then, could positively and negatively prejudice a reviewer toward a book. And critics brought up aesthetic bias frequently when describing which books they selected to review, although it was framed in alternately negative and positive terms when contrasting their experience with traditional review outlets and blogs, respectively.

In traditional book review outlets, critics receive invitations from editors of the book sections to review a specific title. It is crucial to gauge whether the critic's taste - or aesthetic bias - is well suited for the book for both the editors making the invitation and the reviewer deciding whether or not to accept the assignment. This is because making 'good matches' is key to the perceived fairness and legitimacy of a review. When a mismatch occurs, a critic might write a negative review of a book, not because of specific qualities of the book under consideration, such as unconvincing characters or confusing plot, but because of his or her own negative prejudice toward a type of work.

One long-time critic, for example, recalls a book she reviewed that was 'all about golf, and I don't know anything about golf, and I don't care about golf!' She ended up writing a very negative review of the book. The reviewer admits that she hated the book, but reflects, 'I'm not sure if it's his [the author's] fault or mine'. What this reviewer means is that she could not be sure her evaluation was due to an idiosyncratic distaste for 
golf or whether the book was really just that bad. One book review section editor describes situations such as 'setting a book up' for unfair reviews.

Critics do their best to avoid these scenarios; for instance, in the previous example, the reviewer expresses regret that she had not simply declined the book on golf since she was not in a position to appreciate it. And although good and bad matches involve a pairing of critics' aesthetic biases with the tone or content of a novel, critics were most vocal about the dangers of aesthetic bias in the form of mismatches when describing their experiences reviewing for traditional news outlets. Reviewers thus articulated the importance of recognizing the contents of their aesthetic biases as a tool for both qualifying and disqualifying themselves as appropriate reviewers when it came to selecting which books to review.

In contrast, when it came to book blogs, reviewers were overwhelmingly positive about their reliance on their aesthetic biases to select books to review. Specifically, bloggers characterize the way they select books as not very systematic (i.e. by 'mood' or 'whatever pops up in my reading on the web'), but neither is it random. Moreover, it can be a virtue.

Many respondents saw their aesthetic bias as a tool for making the literary landscape more inclusive insomuch as their idiosyncratic selection process might cast a wider net than that represented by the pages of traditional print media. One popular blogger, who also reviewed in prominent newspapers, purposely contrasts his approach to what he characterized as typical mainstream media behavior ('[L]et me offer a distinction between, say, a newspaper editor and my own particular approach'). He aligns himself with an 'alternative' press or voice by going out of his way to look for 'smaller books ... the independent books' and 'provide meaningful coverage for those books that had been denied their rightful place within newspapers'.3 This blogger likens his selection process to 'punk rock' conjuring the anti-establishment values associated with early cyberculture (cf. Turner and Stets, 2006) and the democratic ethos of blogs (Matheson, 2004). Another blogger explains, 'I really like weird books and I like books written by women. I like small presses and I like foreign literature a lot'. These are the types of books she writes about, and she thus recognizes the value of her blog as being a space for 'more neglected books'.

And yet, just as in the case of book selection for traditional newspaper outlets, reviewers' aesthetic preference and bias can also disqualify them from reviewing other types of books. One blogger explains, 'I'm not particularly interested in women's fiction. I'm not a mystery thriller person'. And she does not write about these types of books on her blog, which have historically and continue to be neglected by mainstream media as well (Verboord, 2011).

For reviewers writing for traditional print outlets, being aware of the limits of one's prejudice is important for ensuring that the coverage one provides for the books is not distorted by the limits of one's taste; for example, if one is prejudiced against historical fiction, one cannot fairly report on it. When writing for a personal blog, bias can be celebrated insomuch as it actually provides an admittedly idiosyncratic but alternative selection system for books that might not otherwise be covered in mainstream review sections. The issue of taste, and its role in providing balanced reviews, is treated quite differently in blogging than in traditional reviewing. 
This difference, however, is partially an artifact of the editorial structure of traditional review outlets, wherein critics are assigned books they might not otherwise have read. And a blogger is unlikely to select a book that they do not have the potential to appreciate. The issue of a 'good match', in this way, is a moot issue. But both practices share a common rooting, in the minds of reviewers, in pursuing fairness or openness: that is, fairness at the level of giving a book fair coverage and fairness at the level of the reviewing field and giving a larger sample of books coverage.

\section{Emotions}

'When a book is good, a book is good. And I'll identify it usually in a very sort of visceral, maybe even primitive emotional manner', explains one reviewer. Emotions are understood as very private and personalized experiences - and critics describe reading as an intrinsically emotional activity. Critics emphasize that their emotional responses while reading books operated as tools for gauging the success of the writing. For example, feelings of being 'swept away' or 'engaged' by a narrative were common indicators that a book was working. How, then, do reviewers utilize and represent these emotional experiences in their cultural journalism?

Beginning with the traditional print reviewing, I find that reviewers rely on a dualism between emotion and rationality (Haidt, 2001). The above critic who describes reading as a 'visceral' and 'emotional' activity clarifies that her job as a reviewer is 'to articulate emotion in a rational format', thereby placing emotion at odds with good journalism (Jacobs and Townsley, 2011; Pantti, 2010). One step toward this articulation was through their work with a review section editor.

When I asked critics who reviewed for both newspapers and blogs about differences in the two experiences, critics were most likely to emphasize working with an editor as a key distinction. As one reviewer puts it, the difference is 'not so much because [the review is] being read on a screen versus being read on a page' but how editors helped to act as a 'filter between the critic and her audience'. Probing further to understand what working with an editor contributed to reviewers' processes, the same critic elaborates:

[T]here is something quite different about undergoing the process of being edited [that] is crucial because I think it's very easy to say what you like. It's not as easy to show readers why they should also like it.

This idea of showing readers why they might like a book rather than just telling them echoes the values expressed by journalists that while writing in a way that engages readers' emotions can be valuable, the journalists' emotions should not be part of the story (Wahl-Jorgensen, 2013).

The 'ritual' 4 of working with an editor, then, is not to help authors figure out what they think (which is informed by their emotional reaction while reading the book) but to help them articulate why the readers might reach the same conclusion. And this is achieved through the selective inclusion of, for instance, plot details and excerpts, which are meant to evoke the same emotional response that the critic had while reading (i.e. 'showing' readers why they might like or dislike a book for the same reason that the critic did). In doing so, critics effectively externalize the 'locus of emotion' (WahlJorgensen, 2013) 
by (1) framing emotional responses as properties of the text rather than their idiosyncratic responses to a book5 and (2) outsourcing emotions to the readers.

The norms surrounding how emotionality should factor into bloggers' practices were quite different. The idea of publicizing the self and foregrounding one's persona as a form of branding and a means to attract and maintain readership is central to the reality of running a blog (Christin, forthcoming). Thus, many bloggers featured their specificity and particularity as readers - including featuring their emotional reactions - when writing reviews.

In formal terms, the emotionality of the blogger is conveyed through the particular tone and voice of the writing. For example, the following describes the imperative toward a personal and intimate tone as presenting a 'character'. When I asked one respondent what made his blog successful, he argued,

[W] hat makes all, any successful blog stand out is just the character of the person hosting the blog. It's all about the personality behind the blog, the voice, the ... you know, people will come to my blog because they knew they were going to get certain things.

He continues that what readers would get was book commentary that was 'fairly straight talking', 'entertaining', yet also 'serious minded'.

Several bloggers emphasized the informality of their tone and approach to their blog writing as a form of emotional authenticity. Many bloggers reported that they felt free to be more 'sloppy' or include 'unfinished thoughts' when writing about books on their blogs versus when writing for other review outlets; for instance, one blogger warned her readers that one book was so offensive that it made her want to throw it against the wall. Here, we see the locus of emotion as localized squarely within the reviewer as an individual. To characterize expressions such as 'sloppy' and 'unfinished' accords with the dualism of emotionality and rationality, yet many bloggers insist that what they write on their blogs are similar to, if not sometimes exceeding, the quality of reviews they have written for print publications.

In other words, the 'sloppiness' and rawness blog writing does not, in their minds, equate to lower quality or is not valued: instead, this is valued as a way to build trust with potentially alienated audiences seeking an alternative to the mainstream media (Matheson, 2004; Pavlik, 2001). As one reviewer reflects,

You can kind of get to know [bloggers], get to know who they are ... what kinds of things they like to read, how they write and whether or not they're being honest, whether or not you can trust their opinions.

Hence, the personalized place from which bloggers write and their presentation of their emotions are a conscious decision and relate to building trust with the reader.

Emotions are understood as an intrinsic part of reading and reviewing processes. But how critics represent their emotions in their review varies. When writing for traditional review outlets, critics emphasize the importance of externalizing their initial emotional responses as readers into a 'rational' format in their reviews. And working with editors was seen as facilitating this. When writing for blogs, reviewers embrace rather than 
efface their emotions and other expressions of particularity. The tone of traditional reviews is formal and can be described as a 'voice from nowhere' perspective insomuch as reviewers efface their personal emotions while still communicating their personal judgment about a book. In contrast, it is the voice from a very particular someone that is a defining feature of many book blogs. But in both cases, the degree to which critics feature or conceal their wrestling with the reading and contents of the book as agents in this knowledge-making process is part of a broader attempt to cultivate trust and transparency between themselves and their audience.

\section{Self-interest}

One of the essential principles of journalism is that journalists are willing to put the needs of their readers ahead of their own interests and opinions (Kovach and Rosenstiel, 2001). Practicing this value would entail journalists weighing the public interest over their own (be they economic, political, professional, etc.) when making decisions about how to put together an article - this assuming that what constitutes the public interests are well defined. As Jaakkola (2014: 547, 2015) notes, cultural journalists are faced with striking a balance between the commercial and aesthetic implications of their work. The book reviewers I interviewed emphasized that their goal for writing reviews was not to sell books but to inform the general public about new books as part of a broader cultural conversation. And this was true whether critics were writing for traditional review outlets or blogs.

In case of the traditional newspaper critic, concerns about self-interest came up when weighing the double potential of book reviews to bring awareness not only to the book under review but also to the person writing the review. For example, one reviewer speaks to the publicizing effect of reviewers' bylines, which appear at the bottom of their articles:

If you're a person who reads book reviews then you think, 'Well, oh look, here's a review by $[\mathrm{X}]$ ', so The New York Times asked her to write this. She really must be a good writer ... I should go read - you know, I forgot that I really like her writing, and what's the name of that book?

Oh, here it is, right here [the byline].

Most critics are themselves published authors and review on the 'side' of their other professional activities (Janssen, 1998). And writing reviews offered them an opportunity to promote their own work as writers.

While the goals of writing an engaging article and a thoughtful review are not fundamentally incompatible, feelings of conflict over how to prioritize these goals were a common occupational hazard. One reviewer explained the conflict this way:

I feel like, you know, there's constantly this tension between wanting to sort of show off your own erudition and write some snappy kind of funny lines at the expense of the work, on one hand, and then awareness that that's a little morally debase. 
What is morally debase is that the reviewers' self-interest in demonstrating their erudition ironically comes at the cost of a serious analysis of the books under review. Striking a balance between self-publicizing and giving due consideration to the book under review was a perennial concern for critics.

Bloggers reported a similar tension between self-interest and fulfilling the needs of their audience; however, the meaning of self-interest was more literal. One of the benefits of blogging, mentioned by respondents, was that blogging enabled them to have a two-way conversation with others, unlike traditional review formats wherein critics engage in a one-way flow of information. However, simply stating whether one likes or dislikes a book is a kind of monologue insomuch as there is little for the reader to respond to. One respondent describes the work of a blogger she dislikes as posting two to three paragraph reviews of books that largely contain a 'plot synopsis, and then she'll [write], "I liked it,"' or 'I didn't like it'. 'I give it two stars or three stars out of five', or whatever. 'It's like that doesn't tell me any more really than reading the back of the book'. This was a common criticism. ${ }^{6}$

Blogging is often understood as a dialogic medium (Rettberg, 2008), and many people who blog explain that part of their motivation is to have a conversation about books with like-minded people, meaning other avid readers. Therefore, part of serving the readers of a blog involves providing them with something to discuss and debate rather than just using blogs as a way to write about their personal (or self) interests while disregarding the interests of their audience. And like critics who reviewed exclusively for traditional news outlets, bloggers expressed that the value of their work goes beyond 'simply blogging book recommendations'.

In both traditional and new media forms, book reviewers concern themselves with balancing their own needs and those of their audience. In traditional reviewing platforms, critics work to balance writing a review in which they can insert their own analyses and writing styles in ways that will raise awareness of their own profiles, yet still provide an accurate and thoughtful treatment of the book in question. Bloggers balance their self-interest as readers with the needs of their audience by ensuring they offer something of value to readers in the form of their own analysis and ideas in keeping with the dialogic episteme of blogs (Matheson, 2004). In both cases, the degree to which reviewers are properly balancing their individual needs and the needs of their readers is evinced in the level of their analytical engagement with the book as the object of analysis in their reviews - with the dangers being too much in the case of traditional print reviews or too little on blogs.

\section{Discussion and conclusion}

Scholars have effectively problematized objectivity as a professional ideal in contemporary journalistic practice. This study moves the conversation forward by not only pointing to the presence of subjectivity in journalistic practice but also articulating differences and similarities in how subjectivity is cognized and employed by reviewers writing for traditional and new media review outlets. And the analysis has revealed multiple points of variation and convergence in how different modes of subjectivity are understood. 
Beginning with points of convergence, the analysis reveals that bias, emotions, and self-interest are an intrinsic part of reviewers' practices, and each mode of subjectivity was identified as salient - sometimes as vice and sometimes as virtue - across phases of critics' workflow: bias was most often mentioned in relation to the selection of books to review, emotionality was tied to considerations of tone in the content of reporting, and concerns about self-interest were most salient in relation to the perceived audience and mission of cultural journalism. There was also a great degree of overlap in the greater values that reviewers profess to serve at each phase of the review process: fairness when it comes to selecting books to review, reader trust when it came to how they presented their opinions, and public interest as part of good reporting - although reviewers managed subjectivity differently in order to get there. This convergence of values could be an artifact of the data. It is reasonable to suspect that critics hold core values of 'good journalism' that are not discarded or fundamentally transformed by switching from one media platform to another. ${ }^{7}$ This makes reported differences in reviewers' approach to their review processes all the more compelling.

Many of the differences in how subjectivity is treated by reviewers are anchored in how critics represent themselves as active knowers and subjects in their journalistic process. While bias, emotions, and self-interest are issues to be managed and mitigated when writing for traditional review outlets, the same forms of subjectivity are embraced on blogs. The structural 'trigger' may be norms related to the different media: traditional print book-reviewing apparatuses and blogs. But the focus here is on how actors' selective embrace, rejection, and transformations of different forms of subjectivity - alongside rituals of objectivity (Tuchman, 1972) - are part of a stylized representation of themselves as knowers that varies when moving across media.

Previous studies suggest that blogs and legacy media journalists may observe varying epistemic practices, thereby constituting categorically distinct 'interpretive communities' (Robinson and DeShano, 2011; Zelizer, 2009a). But the analysis reveals how journalists can also code-switch between different epistemic styles evidenced by their alternating approach to subjectivity as vice or virtue. I argue that attending to the different ways journalists switch between epistemic styles opens up new ways of rethinking the relationship between different modes of reporting alongside previous efforts characterizing the differences between blogs and traditional reviewing as differences of technological affordances and professionalization (or lack thereof) as has been the case when contrasting old-new media or professional amateur and citizen journalism (cf. Rettberg, 2008).

Focusing on epistemic styles has at least three analytic advantages: first, treating journalists' subjectivity as an object of analysis allows us to gain insight into how subjectivity operates as its own form of knowledge creation independent of being viewed as the negative foil to objectivity (Shapin, 2012). Second, focusing on variations of epistemic styles provides a more inclusive framework for examining journalism by avoiding rigid binaries of legitimate-illegitimate journalism, and even 'hard' and 'soft' news, thereby drawing attention to a blind spot in studies of journalism that typically concerned with reporting on politics and current events to the neglect of cultural journalism, opinion media, and other forms where subjectivity is more prominently featured. Finally, given that the varieties of personalized forms of journalism are on the rise (Coward, 2013; Jacobs and Townsley, 2011), the epistemic style framework offered here focusing on 
Journalism

how bias, emotions, and self-interest operate as modes of subjectivity offers a modest first step toward developing tools for understanding the growing diversity and changing topography of today's journalistic landscape.

\section{Funding}

The author(s) received no financial support for the research, authorship, and/or publication of this article.

\section{Notes}

1. In other words, Shapin (2012) observes a tendency for scholars to bring attention to the presence of subjectivity as a means of dispelling the myth of objectivity in these fields, and the approach to subjectivity leaves it empirically and theoretically underspecified.

2. This distinction between cultural journalism, arts journalism, reviews, and criticism is multiplex. See Jaakkola (2015: 19-25) for a review of conventional understandings and a useful way to conceptualize the boundaries of each. The focus here is on freelance fiction reviewers to examine an 'extreme' case (Eisenhardt, 1989) of the professional embrace of subjectivity and ambivalence that arts reporters have been shown to have toward objectivity more generally (Harries and Wahl-Jorgensen, 2007).

3. Research supports this idea finding that blogs and other new media forums do give attention to writers and genres - including books by smaller presses and women - that are otherwise excluded by traditional review media (Verboord, 2011).

4. These practices correspond to what Tuchman (1972) describes as rituals of objectivity, to the extent that they are strategies and procedures associated with producing 'objective' news; they can also be understood as what Wahl-Jorgensen (2012) calls a ritual of emotionality insomuch as they refer to rules and limits about how emotions can be legitimately infused in book reviewing. 5. Critics' emotional responses (i.e. being swept away or irritated) are depicted as properties of the books - as an effect of the writing - and evidence of the novel's quality (Chong, 2013: 272-274).

5. By contrasting good and bad blogging practices, these bloggers engage in 'news repair' (Lance et al., 1985; Zelizer, 2009a), or more strictly speaking 'review repair', which is beneficial for illuminating how bloggers conceptualize the customary rules surrounding self-interest in their broader community of practice.

6. A similar overlap in values across new forms of journalism, such as citizen journalists, and traditional journalism has been observed by others (Robinson and DeShano, 2011).

\section{References}

Agarwal SD and Barthel ML (2015) The friendly barbarians: Professional norms and work routines of online journalists in the United States. Journalism 16(3): 376-391.

Andersson U and Wadbring I (2015) Public interest or self-interest? How journalism attracts future journalists. Journal of Media Practice 16(2): 126-138.

Barnes M (2008) Passionate participation: Emotional experiences and expressions in deliberative forums. Critical Social Policy 28(4): 461-481.

Benson R and Neveu E (2005) Bourdieu and the Journalistic Field. Cambridge: Polity Press. Blaagaard BB (2013) Shifting boundaries: Objectivity, citizen journalism and tomorrow's journalists. Journalism 14(8): 1076-1090.

Boczkowski PJ (2005) Digitizing the News. Cambridge, MA: The MIT Press. 
Boyatzis RE (1998) Transforming Qualitative Information. Thousand Oaks, CA: SAGE. Calhoun C (2008) Introduction: Habermas and the Public Sphere. Cambridge, MA: The MIT Press.

Chong P (2013) Legitimate judgment in art, the scientific world reversed? Maintaining critical distance in evaluation. Social Studies of Science 43(2): 265-281.

Chong P (2015) Playing nice, being mean, and the space in between: Book critics and the difficulties of writing bad reviews. Moments of Valuation: Exploring Sites of Dissonance. Oxford, UK: Oxford University Press, pp. 133-146.

Christin A (forthcoming) Counting clicks: Quantification and commensuration in online journalism in the United States and France. American Journal of Sociology.

Christin A (2016) Which bloggers get paid? Unpublished manuscript. Clair M and Winter AS (2016) How judges think about racial disparities: Situational decisionmaking in the criminal justice system. Criminology 54(2): 332 359.

Coward R (2013) Speaking Personally: The Rise of Subjective and Confessional Journalism. Basingstoke: Palgrave Macmillan. Daston JL and Galison P (2007) Objectivity. Brooklyn, NY: Zone Books.

De Zúñiga HG, Lewis SC, Willard A, et al. (2011) Blogging as a journalistic practice: A model linking perception, motivation, and behavior. Journalism 12(5): 586-606.

Deuze M, Paterson C and Domingo D (2008) Toward a sociology of online news. In: Paterson C and Domingo D (eds) Making Online News: The Ethnography of New Media Production. New York: Peter Lang, pp. 199-209. Eisenhardt KM (1989) Building theories from case study research. The Academy of Management Review 14(4): $532-550$.

Fiske ST (1993) Social cognition and social perception. Annual Review of Psychology 44: 155-194. Gamson WA (1989) News as framing. American Behavioral Scientist 33(2): 157-161.

Garden M (2016) Australian journalist-blogs: A shift in audience relationships or mere window dressing? Journalism 17(3): 331-347.

Hackett RA (2009) Decline of a paradigm? Bias and objectivity in news media studies. Critical Studies in Media Communication 1(3): 229-259.

Haidt J (2001) The emotional dog and its rational tail: A social intuitionist approach to moral judgment. Psychological Review 108: 814-834.

Harries G and Wahl-Jorgensen K (2007) The culture of arts journalists: Elitists, saviors, or manic depressives? Journalism 86: 619-639.

Hellman H and Jaakkola M (2012) From aesthetes to reporters: The paradigm shift in arts journalism in Finland. Journalism 13(6): 783-801.

Jaakkola M (2014) Witnesses of a cultural crisis: Representations of media-related metaprocesses as professional metacriticism of arts and cultural journalism. International Journal of Cultural Studies 18(5): 537-554.

Jaakkola M (2015) The Contested Autonomy of Arts and Journalism: Change and Continuity in the Dual Professionalism of Cultural Journalism. Tampere: Tampere University Press.

Jacobs N and Townsley E (2011) The Space of Opinion. Oxford: Oxford University Press. Janssen S (1997) Reviewing as social practice: Institutional constraints on critics' attention for contemporary fiction. Poetics 24: 275297. 
Janssen S (1998) Side roads to success: The effect of sideline activities on the status of writers. Poetics 25(5): 265280.

Jasanoff S (2011) The practices of objectivity in regulatory science. In: Camic C, Gross N and Lamont M (eds) Social Knowledge in the Making. Cambridge, MA: Harvard University Press, pp. 307-338.

Kovach B and Rosenstiel T (2001) The Elements of Journalism. New York: Three Rivers Press. Lamont M (2009) How professors think. Cambridge, MA: Harvard University Press.

Lamont M and Huutoniemi K (2011) Comparing customary rules of fairness: Evaluative practices in various types of peer review panels. In: Camic C, Gross N and Lamont M (eds) Social Knowledge in the Making. Cambridge, MA: Harvard University Press, pp. 209-232. Lance W, Lynne A and William GH (1985) Repairing the news: A case study of the news paradigm. Journal of Communication 35(2): 50-56.

Langfeldt L (2004) Expert panels evaluating research: Decision-making and sources of bias. Research Evaluation 13(1): 51-62.

Li D and Walejko G (2008) Splogs and abandoned blogs: The perils of sampling bloggers and their blogs. Information, Communication \& Society 11(2): 279-296.

Lowrey W (2006) Mapping the journalism-blogging relationship. Journalism 7(4): 477-500. Maienschein J (1991) Epistemic styles in German and American embryology. Science in Context 4: 407-427.

Matheson D (2004) Weblogs and the epistemology of the news: Some trends in online journalism. New Media \& Society 6(4): 443-468.

Mitchelstein E and Boczkowski PJ (2009) Between tradition and change a review of recent research on online news production. Journalism 10(5): 562-586.

Ottovordemgentschenfelde S (2016) Organizational, professional, personal: An exploratory study of political journalists and their hybrid brand on twitter. Journalism 18: 64-80.

Pantti E (2010) The value of emotion: An examination of television journalists' notions on emotionality. European Journal of Communication 25(2): 168-181. Pavlik JV (2001) Journalism and New Media. New York: Columbia University Press.

Perlmutter DD and Schoen M (2007) If I break a rule, what do I do, fire myself? Ethics codes of independent blogs. Journal of Mass Media Ethics 22(1): 37-48.

Peters C (2011) Emotion aside or emotional side? Crafting an experience of involvement in the news. Journalism 12: $297-316$.

Pugh A (2013) What good are interviews for thinking about culture? Demystifying interpretive analysis. American Journal of Cultural Sociology 1(1): 42-68.

Reese SD (1990) The news paradigm and the ideology of objectivity: A socialist at the wall street journal. Critical Studies in Media Communication 7(4): 390-409.

Reese SD, Rutigliano L, Hyun K, et al. (2007) Mapping the blogosphere: Professional and citizenbased media in the global news arena. Journalism 8(3): 235-261.

Rettberg JW (2008) Blogging. London: Polity Press. 
Ridgeway CL (2013) Why status matters for inequality. American Sociological Review 79(1): 1-16.

Robinson S and Culver KB (2016) When white reporters cover race: News media, objectivity and community (dis)trust. Journalism. Epub ahead of print 18 August. DOI: 10.1177/1464884916663599.

Robinson S and DeShano C (2011) Anyone can know: Citizen journalism and the interpretive community of the mainstream press. Journalism 12(8): 963-982.

Schudson M (1976) Origins of the Ideal of Objectivity in the Professions. Abingdon: Taylor \& Francis.

Schudson M (2001) The objectivity norm in American journalism. Journalism 2(2): 149-170. Shapin S (2012) The sciences of subjectivity. Social Studies of Science 42(2): 170-184.

Singer JB (2005) The political j-blogger: Normalizing a new media form to fit old norms and practices. Journalism 6(2): 173-198.

Travis JDL and Collins HM (1991) New light on old boys: Cognitive and institutional particularism in the peer review system. Science, Technology, \& Human Values 16(3): 322-341.

Tuchman G (1972) Objectivity as strategic ritual: An examination of newsmen's notions of objectivity. American Journal of Sociology 77(4): 660-679.

Tumber H and Prentoulis M (2003) Journalists under fire: Subcultures, objectivity and emotional literacy. In: Thussu D and Freedman D (eds) War and the Media: Reporting Conflict 24/7. London: SAGE, pp. 215-230.

Turner F (2010) From Counterculture to Cyberculture. Chicago, IL: University of Chicago Press. Turner JH and Stets JE (2006) Sociological theories of human emotions. Annual Review of Sociology 32(1): 25-52.

Verboord M (2009) The legitimacy of book critics in the age of the internet and omnivorousness: Expert critics, internet critics and peer critics in Flanders and the Netherlands. European Sociological Review 26(6): 623-637.

Verboord M (2011) Cultural products go online: Comparing the internet and print media on distributions of gender, genre and commercial success. Communications 36(4): 441-462.

Vos TP, Craft S and Ashley S (2012) New media, old criticism: Bloggers press criticism and the journalistic field. Journalism 13(7): 850-868.

Wahl-Jorgensen K (2012) The strategic ritual of emotionality: A case study of Pulitzer Prizewinning articles. Journalism 14: 129-145.

Wahl-Jorgensen K (2013) Subjectivity and story-telling in journalism: Examining expressions of affect, judgement and appreciation in Pulitzer Prize-winning stories. Journalism Studies 14(3): 305-320.

Ward SJA (2015) The Invention of Journalism Ethics, Second Edition. Montreal, QC, Canada: McGill-Queen's Press.

Zelizer B (2009a) Journalists as interpretive communities. Critical Studies in Media Communication 10(3): 219237.

Zelizer B (2009b) The Changing Faces of Journalism. Abingdon: Routledge. 


\section{Author biography}

Phillipa Chong is an Assistant Professor in Sociology at McMaster University. She is a cultural sociologist who specializes in how we define and evaluate worth: this includes the value we assign to social objects (e.g. books, opinions) and social groups (e.g. experts, artists, minority groups). To date, her empirical focus has been on book reviewers and is currently writing a monograph (with Princeton University Press) exploring how fiction reviewers engage in the dual project of constructing (1) the value of new novels in the absence of objective indicators of aesthetic quality and (2) the legitimacy of their professional judgments, given the recent changes in the mediascape. 